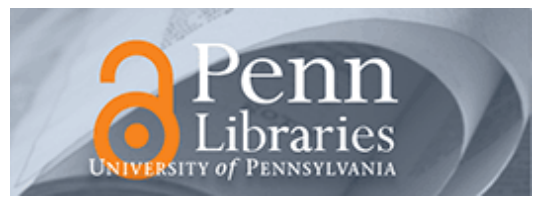

University of Pennsylvania ScholarlyCommons

$9-1-2007$

\title{
National Trends in the Sources of Supply of Teachers in Special and General Education
}

Lynne H. Cook

California State University

Ed Boe

Univer. of Pennsylvania, boe@gse.upenn.edu

Follow this and additional works at: https://repository.upenn.edu/gse_pubs

\section{Recommended Citation}

Cook, L. H., \& Boe, E. (2007). National Trends in the Sources of Supply of Teachers in Special and General Education. Retrieved from https://repository.upenn.edu/gse_pubs/183

Reprinted from Teacher Education and Special Education, Volume 30, Issue 4, September 2007, pages 217-232.

We have contacted the publisher regarding the deposit of this paper in ScholarlyCommons@Penn. No response has been received.

This paper is posted at ScholarlyCommons. https://repository.upenn.edu/gse_pubs/183

For more information, please contact repository@pobox.upenn.edu. 


\title{
National Trends in the Sources of Supply of Teachers in Special and General Education
}

\author{
Abstract \\ This paper addresses the national quantity demand, supply, and shortage of special education teachers \\ (SETs) in comparison to general education teachers (GETs). The main data source was the 1999-00 \\ Schools and Staffing Survey. Results indicated that the total demand for SETs increased $38 \%$ from \\ 240,000 in $1987-88$ to 330,000 in $1999-00$, a rate of growth greater than the $26 \%$ increase observed for \\ GETs. For entering teachers, the reserve pool was the predominant source of supply of both SETs and \\ GETs. However, only $46 \%$ of first-time SETs completed extensive teacher preparation with degree majors \\ in their primary areas of teaching, whereas the comparable figure for GETs was $82 \%$. As an indication of \\ the inadequate supply of extensively prepared teachers in special education, about $28 \%$ of first-time \\ teachers hired in special education positions had completed teacher preparationi in generale education. \\ Finally, a modest decline in the supply of degree graduates in special education has occurred since \\ 1997-98 in spite of the increasing quantity demand for entering SETs.
}

\section{Comments}

Reprinted from Teacher Education and Special Education, Volume 30, Issue 4, September 2007, pages 217-232.

We have contacted the publisher regarding the deposit of this paper in ScholarlyCommons@Penn. No response has been received. 


\section{National Trends in the Sources of Supply of Teachers in Special and. General Education}

Lynne H. Cook \& Erling E. Boe

Abstract: This paper addresses the national quantity demand, supply, and shortage of special education teachers (SETs) in comparison to general education teachers (GETs). The main data source was the 1999-00 Schools and Staffing Survey. Results indicated that the total demand for SETs increased 38\% from 240,000 in $1987-88$ to 330,000 in 1999-00, a rate of growth greater than the 26\% increase observed for GETs. For entering teachers, the reserve pool was the predominant source of supply of both SETs and GETs. However, only $46 \%$ of first-time SETs completed extensive teacher preparation with degree majors in their primary areas of teaching, whereas the comparable figure for GETs was $82 \%$. As an indication of the inadequate supply of extensively prepared teachers in special education, about $28 \%$ of first-time teachers hired in special education positions had completed teacher preparation in general education. Finally, a modest decline in the supply of degree graduates in special education bas occurred since 1997-98 in spite of the increasing quantity demand for entering SETs.

B eginning with the implementation of P. L. 94-142, the shortages of special education teachers (SETs) have been of significant concern to the profession and to policy makers at federal, state, and local levels (Carriker \& Weintraub, 1989). In 1992, a group of 10 professional organizations and representatives of the federal government and its funded projects concluded, "the problems of quality and quantity [italics added] have now achieved

Support for this research was provided by a grant (Award Number H0324C020002) from the Research and Innovation to Improve Services, and Results for Children with Disabilities Program (Ficld Initiated Research Projects, CFDA Number. 84024C), Research to Practice Division, Office of Special Education Programs, the U.S. Department of Education, to Erling E. Boe at the University of Pennsylvania; and by the Center for Research and Evaluation in Social Policy, the Graduate School of Education of the University of Pennsylvania.

Correspondence concerning this article should be addressed to Lynne H. Cook, College of Education, California State University, Dominguez Hills, 1000 East Victoria Street, Carson, California 90747. Email: thcook@csudh.edu pervasive and critical dimensions" (National Clearinghouse on Professions in Special Education, 1992, p. 8). Unfortunately, these teacher shortages significantly limit the capacity of the field of special education to provide quality education and related services to the nation's six million school-age students with disabilities (Office of Special Education Programs [OSEP], 2004)].

Concerned with the continuing shortage of SETs, the Council for Exceptional Children (CEC) Presidential Commission on the Conditions of Special Education Teaching and Learning was charged in 1998 "(1) to identify those barriers that obstruct high-quality special education, and (2) to develop an action agenda that would galvanize the education community to ensure that every student with an exceptionality has a highly qualified teacher who is able to practice under optimal professional conditions and in suitable settings" (Kozleski, 
Mainzer, \& Deshler, 2000, p. 1). The CEC Commission added perspective about the impact of the shortages by noting that thousands of special education teaching positions remain vacant annually and tens of thousands of students with disabilities are taught by teachers with unacceptably large caseloads.

These assertions were quantified by the Study of Personnel Needs in Special Education (SPeNSE), funded by OSEP, U.S. Department of Education (USDE). This national survey of SETs described factors associated with workforce quality. The SPeNSE report of key findings noted the difficulty in separating considerations of teacher quality from those of quantity because increasing vacancies and numeric shortage of applicants led administrators to hire less qualified personnel. Their findings revealed that more than 12,000 special education positions nationwide either were left vacant or were filled by substitutes during the 1999-2000 school year because qualified personnel were not available. Additional indicators of shortage included nearly 5,400 class size waivers and 5,500 caseload waivers sought by administrators and over 50,000 person-days of substitute teaching used per week (Carlson, Brauen, Klein, Schroll, \& Willig, 2002).

Testimony before the President's Commission on Excellence in Special Education (PCESE), which President Bush established in 2001, further amplified the problem. Data summarized in the PCESE report (USDE, 2002 ) indicated that $98 \%$ of the nation's school districts reported shortages of SETs and approximately $10 \%$ of special education positions, or 39,000 positions, were filled by uncertified personnel. There is every indication that the current shortages will continue to grow. For example, McLeskey, Tyler, and Flippen (2004) report projections by the US Bureau of Labor Staristics that between 1998 and 2008 special education teaching positions will grow by nearly $34 \%$ (i.e., approximately 136,000 additional positions) in public and private schools.

A major consideration in the shortage of SETs is inadequacy in their supply. Examination of the adequacy of teacher supply requires

\footnotetext{
'Other major considerations are the misassignment of otherwise qualified SETs to positions or subject matter aress for which they have not been prepared, and the atrition of SETs (either from the profession or through transfer to general education teaching positions).
}

a distinction between two types of teacher demand, and the adequacy of supply in relation to each type, including (a) quantity demand, or the demand for the number of teachers to fill all teaching positions that have been created and funded at the district level, and (b) quality demand, or the demand for teachers with specific qualifications such as certification level, certification field, amount of teacher preparation, and degree major field.

The most straightforward index of the current quantity demand for SETs is the approximately 403,000 full-time equivalent (FTE) teaching positions (for students ages 6-21) in public schools during the 2002-03 school year that have been established and funded to provide instruction for students with disabilities, as reported in OSEP's TwentySeventh Annual Report to Congress (2005). This quantity demand is for a total number of FTE SETs $(403,000)$ to fill a total number of FTE teaching positions $(403,000)$ in special education for students ages $6-21$.

In satisfying the quantity demand for new teachers, degree graduates of teacher preparation programs in special education have been, and will continue to be, a major source in the future. Yer there is evidence that the annual production of new graduates by teacher preparation programs offered by US colleges and universities (i.e., the traditional means for preparing teachers) has been insufficient to meet the current demand (Boe, Cook, Kaufman, \& Danielson, 1996). Kozleski et al. (2000) estimated that the numbers of new teachers being prepared for special education annually are about 17,000 , a number far less than needed to fill teaching vacancies in special education each year (i.e., vacancies created by SETs leaving teaching, transferring to general education positions, and expansion of teaching positions in special education).

Furthermore, many degree graduates of teacher preparation programs are already employed as teachers, and therefore nor available to be recruited to fill open positions. According to national data reported by Snyder and Hoffman for 2000-01 (2003; Table 255), over half of the number of degree graduates in fields of special education teaching occur at the master's degree level. Unfortunately, about $75 \%$ of master's graduates from all fields of teacher preparation are already employed as 
teachers at the time of graduation; thus only about $25 \%$ represent potential new teachers to fill open positions (Boe, Cook, Paulsen, Barkanic, \& Leow, 1999). If traditionally prepared degree graduates are insufficient in number to sarisfy the quantity demand for entering teachers, then other sources must be tapped such as the products of alternative routes to certification (ARC) and the reserve pool of teachers.

In the face of chronic and escalating shortages of SETs, data on the sources of supply of entering teachers is of great importance to policy makers and practitioners who face the consequences of the shortages. Yet very little data of this nature exist. In fact, the only research into sources of SET supply at a national level is that reported by Boe et al. (1996; McLeskey, et al., 2004). In their analysis of data from a national probability sample of public school teachers responding to the 1990-91 Schools and Staffing Survey (SASS), Boe et al. considered the two broad teaching fields (i.e., general education and special education) and examined five primary sources of teacher supply for public schools. The results were highly similar for general and special education teachers. The main source of entering reachers in $1990-91$ was the reserve pool (68\% in special education; $69 \%$ in general education), that includes delayed entrants and returning experienced reachers. Other sources were recent graduates at the bachelor's degree or higher levels with a degree major in any field or discipline $(24 \%$ in special and general education), and teachers who migrated from private. schools to public schools ( $8 \%$ in special education; $7 \%$ in general education). Differences between special and general education were especially noteworthy in two respects: (a) the annual inflow of entering SETs (i.e, 9\%) was greater than for entering GETs (i.e, 6\%), and (b) a higher percentage of positions in special education than in general education were filled with reentering experienced teachers.

This information about the sources of supply of SETs, in comparison with GETs, now needs to be updated and expanded. In recent years, the need for a comprehensive knowledge base for the teaching force in special education has been reiterated by CEC's
Commission on the Conditions for Special Education Teaching and Learning (2000) and by several researchers (Miller, Brownell, \& Smith, 1999; McLeskey, et al, 2004; Zabel \& Zabel, 2001). Basic issues abour this teaching force are the extent of, and trends over time in, the quantity demand for SETs and the sources of teacher supply that satisfy this demand. For example, trend data up to the mid-1990s led to concern that the supply of reentering experienced teachers from the reserve pool was becoming depleted (OSEP, 1998).

In response to these issues and concerns, we have undertaken an analysis of teacher supply and demand in public schools (i.e., for SETs in comparison with GETs) using the most recent national data (the 1999-00 SASS), as well as data from three prior administrations of SASS. More specifically, the main questions addressed by this research were:

1. How large is teacher quantity demand and shortage?

2. To what extent do major sources of supply satisfy the total quantity demand for teachers?

3. To what extent do sources of supply satisfy the quantity demand for entering teachers?

4. To what extent do sources of supply satisfy the quantity demand for first-time teachers?

5. What are trends in the annual supply of degree majors in teacher preparation?

\section{Method $^{2}$}

\section{Data Sources}

The main data source was teachers' self reports to the most recently available version (1999-2000) of the Public School Teacher Questionnaire (PSTQ), a component of SASS, conducted by the National Center for Education Statistics (NCES), USDE. The PSTQ provided information directly relevant to this research about teacher supply (e.g., continuing vs. entering teachers), amount of teacher preparation (i.e., extensive, some, none), and teaching field (i.e., special vs.

\footnotetext{
${ }^{2}$ Detailed descriptions of variables analyzed and data analysis procedures are presented in the Appendix.
} 


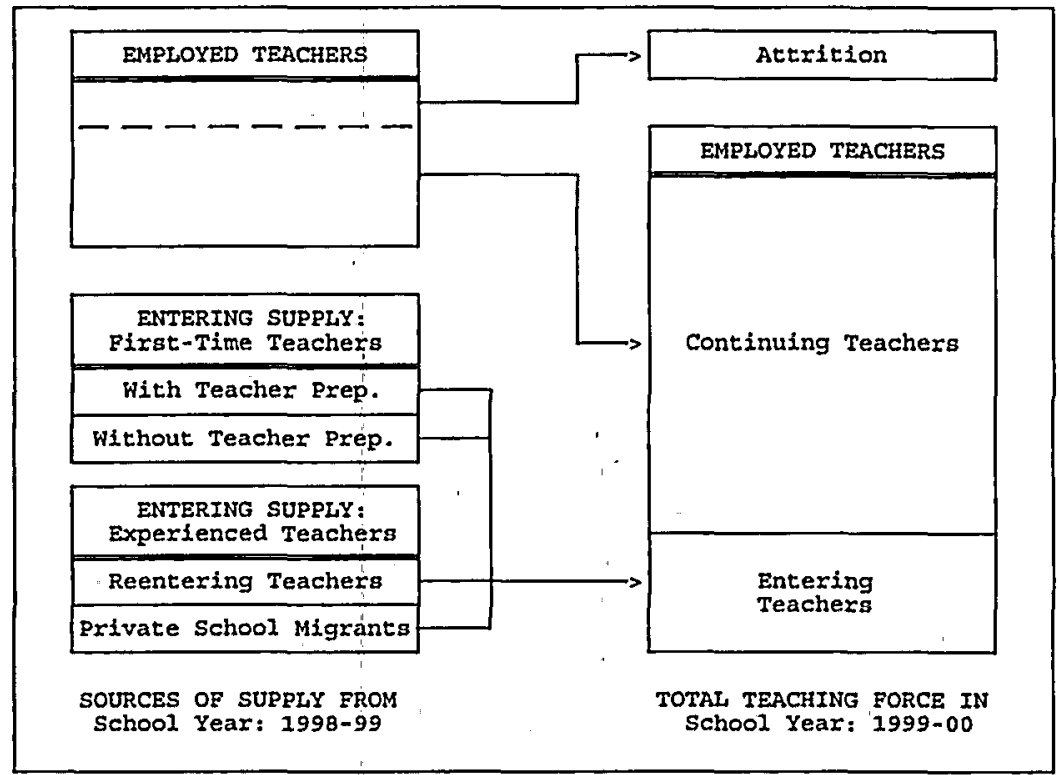

Figure 1. System Model of Sources of Supply of Public School Teachers from School Year 1998-99 to 1999-2000

general education). In addition, data for teacher supply were obtained from versions of the PSTQ from the 1987-88, 1990-91, and 1993-94 administrations of SASS to permir analyses of trends.

In addition to SASS, longitudinal data on the number of degree graduates with majors in teacher preparation programs were obtained from the Integrated Postsecondary Education Data System (IPEDS), also provided by NCES. These data were obtained from a series of annual NCES reports entitled 'Digest of Education Statistics (e.g., Snyder \& Hoffman, 2003).

\section{Teachers Studied}

The 1999-2000 PSTQ provides nationally representative estimates of the numbers of public school teachers of the various types analyzed in this research. Specifically, PSTQ data were obtained from a large national probability sample of public school teachers $(\mathrm{N}=53,105$, including public charter school teachers) with a weighted questionnaire response rate of $83 \%$. This yielded a sample of $44,896 \mathrm{~K}-12$ teachers who completed the PSTQ (i.e, 4,919 SETs; 39,977 GETs).

\section{Design: Study of Sources of Teacber Supply}

The research was designed to analyze, from a national perspective, trends in the sources of supply of teachers employed in public schools. Based on the responses to PSTQ, trends in the supply of both SETs and GETs were tracked during school years 1987-88, 1990-91, 199394, and 1999-00. In particular, these trends focused on two main sources of supply of public school teachers: those entering the teaching force each year and those continuing in public schools from the prior year.

Further analyses were performed of entering teacher supply for school year 1999-00. This phase of the research focused on the sources of supply of public school teachers who entered the teaching force in 1999-00. The specific sources of supply are depicted in Figure 1. Teachers with preparation were subdivided into those with extensive teacher preparation and those with only some preparation. In addition, first-time teachers were subdivided into those who entered within a year of graduation (i.e., recent graduates) and who entered more than a year after graduation (i.e., delayed entrants). First-time teachers were 
also subdivided into those who graduated with a degree major in a field of teacher preparation in either special or general education and who graduated with a degree major in some other field.

\section{Design: Study of Degree Graduates with Majors in Teacher Preparation}

In addition to the detailed study of the sources of teacher supply, we used data from IPEDS to study trends (from 1977 to 2002) in the supply of degree graduates with an education major in an area of teaching in special education (e.g., learning disabilities) and general education (e.g., mathematics education). Trend data from 1977 to 2002 were produced separately for bachelor and master's degree graduates from teacher preparation programs in special education and in general education.

These graduates represent the supply of potential entering teachers. However, some of these graduates (particularly master's degree graduates) might already be employed as teachers at the time of degree completion. Consequently, by using data from PSTQ on continuing teachers from 1998 to 1999 , we estimate the number of the 1999 'master's degree graduates in special education who were already employed as teachers at the time of degree completion.

\section{Results and Discussion}

To facilitate the presentation of the results of this research on the sources of supply of public school teachers nationally, this section is organized in response to five main questions about teacher supply. Parallel analyses were made for special and general education to permit comparisons between these two broad teaching fields.

\section{How Large is Teacher Quantity Demand and Shortage?}

As described in the introduction, the national quantity demand for public school teachers is the number of teachers needed to fill all teaching positions that have been created and funded at the district level. The best available measure of quantity demand for teachers is the total number of employed teachers (See Table 1 for Total Teachers). This is because only a small percentage of all funded teaching positions remain vacant. In special education, about, $1.0 \%$ (or about 3,600 positions) of total teaching positions were vacant in 1997-98 (the last date for which vacancy data were collected) (OSEP, 2000, Table AC2). In general education, about 0.3 percent of teaching positions were left vacant or filled by a substitute teacher and another 0.20.3 percent of teaching positions were withdrawn because a qualified applicant could nor be found (1993-94 SASS data, the last year for which such data were collected; Henke, Choy, Geis, \& Broughman, 1996). These percentages quantify the quantity shortage of teachers. Though very small; the quantity shortage of SETs was about double that of GETs.

Apart from the small percentage of vacant teaching positions, the total quantity demand for K-12 SETs during the 1999-00 school year was approximately 330,000 based on SASS data (see Table 1). This compares with a demand for 2,668,000 GETs during the same year. These counts are based on the number of teachers (i.e., full-time and part-time) who identified their main teaching assignment as one of these two broad fields of teaching. Similarly, OSEP (2002) reported about 359,000 FTE SETs for children and youth with disabilities ages 6-21 during the 1999-00 school year. The SASS and OSEP estimates of total employed SETs are reasonably close given the differences in survey methods and definitions. Examination of quantity demand over the 12-year period shown in Table 1 shows a pattern of increasing demand for both GETs and SETs. However, the demand for SETs grew at a considerably higher rate than for GETs (38\% vs. $26 \%$, respectively) from 1987 88 to $1999-00$.

\section{To What Extent do Major Sources of Supply Satisfy the Total Quantity Demand for Teachers?}

As seen in Table 1, the predominant source of supply of public school teachers in any one school year has been those continuing in teaching employment from the previous year (i.e., approximately $92 \%$ in special education and general education during the 1999-00 school year). Special education has been 
Table 1. Sources of Supply of Total Public School Teachers in Special and General Education: National Trends in the Percentage of Teachers by Major Supply Sources for Four School Years

\begin{tabular}{|c|c|c|c|c|c|c|c|c|c|}
\hline \multirow{3}{*}{$\begin{array}{l}\text { Source of Teacher } \\
\text { Supply }\end{array}$} & \multirow[b]{3}{*}{ Statistic } & \multicolumn{8}{|c|}{ Teaching Field } \\
\hline & & \multicolumn{4}{|c|}{ Special Education by Year } & \multicolumn{4}{|c|}{ General Education by Year } \\
\hline & & $1987-88$ & $1990-91$ & $1993-94$ & $1999-00$ & $1987-88$ & $1990-91$ & $1993-94$ & $1999-00$ \\
\hline I. Continuing & $\begin{array}{l}\text { Column \% } \\
\text { Std Err \% }\end{array}$ & $\begin{array}{r}91.5 \% \\
0.5 \%\end{array}$ & $\begin{array}{r}91.2 \% \\
0.7 \%\end{array}$ & $\begin{array}{r}92.9 \% \\
0.5 \%\end{array}$ & $\begin{array}{r}92.2 \% \\
0.5 \%\end{array}$ & $\begin{array}{r}93.8 \% \\
0.1 \%\end{array}$ & $\begin{array}{r}94.1 \% \\
0.2 \%\end{array}$ & $\begin{array}{r}93.7 \% \\
0.2 \%\end{array}$ & $\begin{array}{r}92.1 \% \\
0.2 \%\end{array}$ \\
\hline \multicolumn{10}{|l|}{ II. Entering } \\
\hline $\begin{array}{l}\text { A. First-Time } \\
\text { B. Experienced } \\
\text { Subtotal: Entering }\end{array}$ & $\begin{array}{l}\text { Column \% } \\
\text { Std Err \% } \\
\text { Column \% } \\
\text { Std Err \% } \\
\text { Column \% } \\
\text { Std Err \% }\end{array}$ & $\begin{array}{l}2.8 \% \\
0.3 \% \\
5.8 \% \\
0.4 \% \\
8.5 \% \\
0.5 \%\end{array}$ & $\begin{array}{l}3.6 \% \\
0.4 \% \\
5.2 \% \\
0.6 \% \\
8.8 \% \\
0.7 \%\end{array}$ & $\begin{array}{l}3.9 \% \\
0.4 \% \\
3.2 \% \\
0.4 \% \\
7.1 \% \\
0.5 \%\end{array}$ & $\begin{array}{l}4.0 \% \\
0.4 \% \\
3.8 \% \\
0.3 \% \\
7.9 \% \\
0.5 \%\end{array}$ & $\begin{array}{l}2.5 \% \\
0.1 \% \\
3.7 \% \\
0.1 \% \\
6.2 \% \\
0.1 \%\end{array}$ & $\begin{array}{l}3.4 \% \\
0.2 \% \\
2.6 \% \\
0.1 \% \\
5.9 \% \\
0.2 \%\end{array}$ & $\begin{array}{l}3.9 \% \\
0.1 \% \\
2.4 \% \\
0.1 \% \\
6.3 \% \\
0.2 \%\end{array}$ & $\begin{array}{l}4.3 \% \\
0.2 \% \\
3.6 \% \\
0.1 \% \\
7.9 \% \\
0.2 \%\end{array}$ \\
\hline Toral Teachers & $\begin{array}{l}\text { Column \% } \\
\text { Natl Est } \\
\text { SE Est } \\
\text { Sample (n) }\end{array}$ & $\begin{array}{c}100 \% \\
240 \\
3.8 \\
4,307\end{array}$ & $\begin{array}{c}100 \% \\
274 \\
6.5 \\
5,054\end{array}$ & $\begin{array}{c}100 \% \\
270 \\
5.2 \\
5,288\end{array}$ & $\begin{array}{c}100 \% \\
330 \\
6.3 \\
4,919\end{array}$ & $\begin{array}{c}100 \% \\
2,079 \\
11.9 \\
36,215\end{array}$ & $\begin{array}{c}100 \% \\
2,277 \\
20.3 \\
41,545\end{array}$ & $\begin{array}{c}100 \% \\
2,282 \\
19.6 \\
41,706\end{array}$ & $\begin{array}{c}100 \% \\
2,668 \\
18.3 \\
39,977\end{array}$ \\
\hline
\end{tabular}

Note. Data from the 1987-88, 1990-91, 1993-94 and 1999-2000 Schools and Staffing Surveys, National Center for

Education Statistics, USDE.

- Nationally weighted column percentages of the toral number of special and general education teachers. Std Err \% is the standard error of the column percentages. Natl Est is the nationally weighted estimate of the tocal number of teachers. SE Est is the standard error of the national estimates.

b Nationally estimated numbers in 1,000's.

reasonably stable at the $92 \%$ level over time, while general education seems to have declined slightly from about $94 \%$ in $1990-91$ to $92 \%$ in 1999-00. A high percentage of continuing teachers is desirable, of course, because it represents stability in the teaching force.

Entering teachers accounted for the remaining $8 \%$ of teacher supply, a percentage that was about equally split in 1999-00 between first-time teachers and experienced teachers (including reentering experienced teachers and private school migrants). In both special and general education, there has been a trend since 1987-88 toward a higher percentage of first-time teachers as a source of supply to meet total teacher demand, a fact that puts pressure on the teacher education programs nationally to produce more and more graduates.

Note that the 26,000 entering SETs and 210,000 entering GETs accounted for about $7.9 \%$ of total teachers in each field/during the 1999-00 school year. Together, they represent 236,000 entering teachers, per year, or $2,360,000$ extrapolated at this level during the next 10 years. This level of supply is well over the 200,000 teachers per year (or $2,000,000$ in ten years) said to be needed by those who express alarm about the potential insufficiency of sources of supply to meet the prospective demand for entering teachers (National Commission on Teaching and America's Future, 1996). It is obvious that there has been, and likely will be, sufficient quantity supply of teachers to meer future quantity demand. However, without considering teacher qualifications, simply meeting the quantity demand for teachers is nor an adequate solution. This legitimate concern about the quality of the teacher supply will be addressed later in this paper.

\section{To What Extent do Sources of Supply Satisfy the Quantity Demand for Entering Teachers?}

The two major components of entering teacher supply (i.e., first-time teachers and experienced teachers) in public schools for 1999-00 are illustrated in the bottom half of Table 1. In Table 2, both of these major supply sources are subdivided and organized 
Table 2. Entering Special and General Education Teachers in Public Schools: National Estimates of the Percentage of Teachers by Seven Sources of Entering Supply for the 1999-2000 School Year

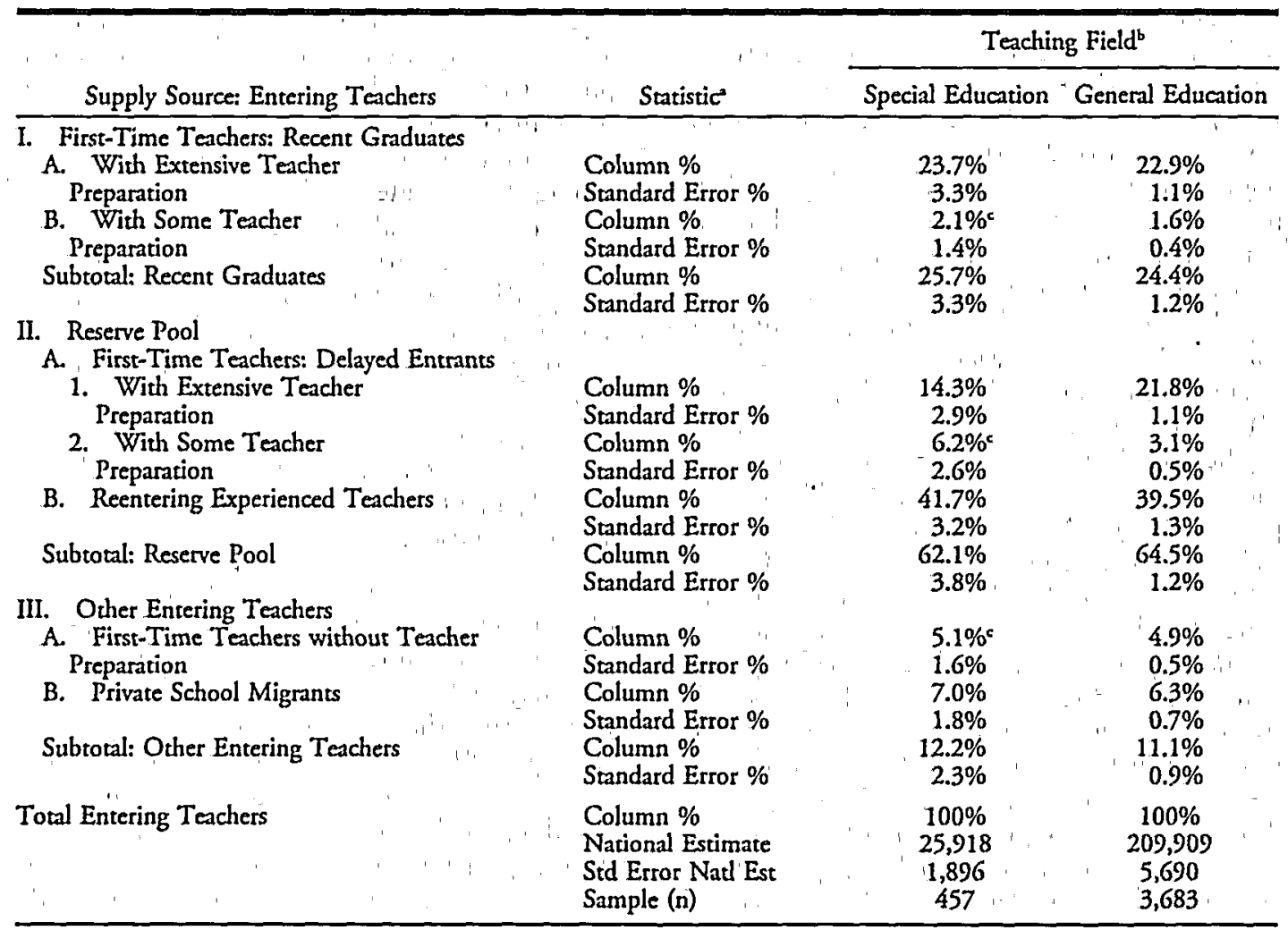

Note. Data from the 1999-2000 Schools and Staffing Surveys; National Center for Education' Statistics, USDE.

- Nationally weighted column percentages of the total number of entering special and general education teachers. Standard Error \% is the standard error of the column percentages. National Estimate is the nationally weighted estimates of the total number of entering teachers. Std Error Natl Est is the standard error of the national estimates.

b The supply source by teaching field $(7 \times 2) \chi^{2}$ was $23.3(p<.001)$.

- Sample size $(n)$ is less than 30 .

into three categories: (a) recently graduated (during 1999) first-time teachers with teacher preparation, (b) teachers in the reserve pool, and. (c) other entering teachers. Each of these three categories of entering teacher supply is described in turn below.

Recenr degree graduates of teacher preparation programs have long been a substantial source of first-time teachers. This source produced about a quarter of all entering teachers with extensive preparation in 1999$00(23.7 \%$ of entering SETs and $22.9 \%$ of entering GETs, as seen in Table 2). These percentages are roughly similar to the percentages of entering recent graduates reported by
Boe et al. (1996) based on the 1990-91 SASS and by Boe, Bobbitt, Cook, and Barkanic (1998) based on the 1993-94 SASS. In addition, the-percentages of recent graduates with only some preparation are shown in Table 2.

In defining extensive preparation, we used information provided by. PSTQ about the length of practice teaching (i.e., an unpaid supervised experience provided by traditional programs, but nor by ARC programs). In contrast, ARC programs provide participants with full-time employment as teachers (i.e., a paid supervised experience). Based on further analyses, it appears that ARC participants 
regarded their full-time paid employment as equivalent to practice teaching when they answered the practice teaching question. Accordingly, our category of extensive teacher preparation includes both traditional graduates and ARC completers. As observed by Sindelar, Daunic, and Rennells (2004) and Brownell, Hirsch, and Seo (2004), teacher preparation of high intensity has been shown in other research to produce effective teachers regardless of whether preparation was obtained by traditional or ARC programs.

The reserve pool was the predominant source of entering teachers (accounting for $62.1 \%$ of entering SETs and $64.5 \%$ of entering GETs, see Table 2). Reentering experienced teachers represented the largest component of the reserve pool, and accounted for the largest percentage of all entering teachers for both special and general education $(41.7 \%$ and $39.5 \%$, respectively). By 1993-94, reentering experienced teachers as a source of entering teacher supply had declined (to $33 \%$ for special education and $32 \%$ for general education) from earlier highs in 1987-88 (60\% and 54\%, respectively; Boe et al,, 1998). In light of this trend, OSEP (1998) voiced a concern that "this source of supply is rapidly becoming depleted" (Section III, p. III-17). It is now apparent that, by 1999-00, this source of supply did not become depleted. Instead, the declining trend previously observed in the supply of reentering 'experienced teachers has reversed.

Delayed entrants (i.e., first-time prepared teachers who postponed entry into teaching employment by more than one year following degree completion) also represented a substantial component of the reserve pool (20.5\% of entering SET and $24.9 \%$ of entering GETs, as seen in Table 2). With respect to the reserve pool overall, the available evidence clear indicates that it served as the predominant source of entering teachers in 1999-00 and that it appears to be a stronger source of supply in 1999-00 than it was eight years earlier in 1993-94 (Boe et al., 1998).

Other sources of entering teacher supply include first-time teachers withour teacher preparation (i.e., $5.1 \%$ of entering SETs and $4.9 \%$ of entering GETs) and private school migrants transferring to public schools (i.e., $7.0 \%$ of entering SETs and $6.3 \%$ of entering
GETs). Private school migrants are individuals with teaching experience, whereas first-time teachers withour preparation have no formal credentials for assuming teaching positions. The fact that they were hired to fill open positions in special education is an indication the shortage of prepared teachers.

Although the differences in column percentages in Table 2 of entering teachers in special and general education were statistically significant, the differences were too small to be noteworthy. Essentially, the sources of teacher supply produced equivalent percentages of entering teachers in special and general education.

\section{To What Extent do Sources of Supply Satisfy the Quantity Demand for First- Time Teachers?}

As shown in Table 2, approximately half of all entering public school teachers in 199900 were first-time teachers (i.e., $51.3 \%$ of entering SETs and $54.4 \%$ of entering GETs, representing the sums of rows IA, IB, IIAI, IIA2, and IIIA). The first-time teachers with extensive preparation are presented in more detail in Part I of Table 3 in terms of their field of degree major ${ }^{3}$. A substantial and comparable majority of all first-time teachers in both special and general education completed extensive teacher preparation (i.e., $74.0 \%$ and $82.4 \%$, respectively). However, $17.6 \%$ of firstrime SETs majored in a field of general education only, while less than $0.5 \%$ of firsttime GETs majored in a field of special education only.

This analysis of first-time teachers entering special education reveals a serious shortage of qualified first-time SETs. Only $46 \%$ of firsttime SETs had both completed extensive teacher preparation specifically with degree majors in special education. By contrast, $81.9 \%$ of GETs with extensive preparation completed majors relevant to general education (i.e., those with majors in a field of teacher preparation in general education plus those majors in other fields).

\footnotetext{
${ }^{3}$ The small sample $(<30)$ of SETs completing only some teacher preparation precluded a similar analysis of this group according to their field of degree major.
} 
Table 3. First-Time Special and General Education Teachers in Public Schools: National Estimates of the Percentage of Teachers by Teacher Preparation and Degree Major for the 19992000 School Year

\begin{tabular}{|c|c|c|c|}
\hline \multirow[b]{2}{*}{ Supply Source: First-Time Teachers } & \multirow[b]{2}{*}{ Statistic } & \multicolumn{2}{|c|}{ Teaching Field } \\
\hline & & Special Education & General Education \\
\hline $\begin{array}{l}\text { W. With Extensive Teacher Preparation } \\
\text { A. Special Education Teacher } \\
\text { Preparation Major } \\
\text { B. Both Special and General Education } \\
\text { Teacher Preparation Major } \\
\text { C. General Education Teacher } \\
\text { Preparation Major } \\
\text { D. Other Major } \\
\text { Subtotal: With Extensive Teacher } \\
\text { Preparation } \\
\text { II. With Some Teacher } \\
\text { Preparation } \\
\text { III. Without Teacher Preparation }\end{array}$ & $\begin{array}{l}\text { Column \% } \\
\text { Standard Error \% } \\
\text { Column \% } \\
\text { Standard Error \% } \\
\text { Column \% } \\
\text { Standard Error \% } \\
\text { Column \% } \\
\text { Standard Error \% } \\
\text { Column \% } \\
\text { Standard Error \% } \\
\text { Column \% } \\
\text { Standard Error \% } \\
\text { Column \% } \\
\text { Standard Error \% }\end{array}$ & $\begin{array}{r}34.8 \% \\
5.7 \% \\
11.6 \% \\
3.2 \% \\
17.6 \% \\
3.8 \% \\
9.9 \%^{\mathrm{c}} \\
3.3 \% \\
74.0 \% \\
5.9 \% \\
16.1 \%{ }^{\mathrm{c}} \\
5.6 \% \\
10.0 \%{ }^{\mathrm{c}} \\
2.9 \%\end{array}$ & $\begin{array}{r}0.5 \% \\
0.2 \% \\
1.2 \%^{c} \\
0.5 \% \\
53.5 \% \\
2.0 \% \\
27.2 \% \\
1.7 \% \\
82.4 \% \\
1.4 \% \\
8.6 \% \\
1.0 \% \\
9.0 \% \\
0.9 \%\end{array}$ \\
\hline Total First-Time Teachers & $\begin{array}{l}\text { Column \% } \\
\text { National Estimate } \\
\text { Std Error Natl Est } \\
\text { Sample (n) }\end{array}$ & $\begin{array}{c}100 \% \\
13,292 \\
1,412 \\
209\end{array}$ & $\begin{array}{c}100 \% \\
113,907 \\
4,258 \\
1,950\end{array}$ \\
\hline
\end{tabular}

Note. Data from the 1999-2000 Schools and Staffing Surveys, National Center for Education Statistics, USDE.

- Nationally weighted column percentages of the total number of first-time special and general edueation teachers. Standard Error \% is the standard error of the column percentages. National Estimate is the nationally weighted estimates of the total number of first-time teachers. Std Error Natl Est is the standard error of the national estimates.

- The supply source by teaching field $(6 \times 2) \chi^{2}$ was $764.1(p<.001)$.

- Sample size ( $\mathrm{n}$ ) is less than 30 .

\section{What are Trends in the Annual Supply of Degree Majors in Teacher Preparation?}

National trends in the production of bachelor's and master's degree graduates with majors in an area of teacher preparation are shown in Figure 2 for special and general education. During the past six years, the total production of teacher education graduates has been gradually increasing in general education, while it has been gradually decreasing in special education-a trend in special education that runs counter to the increasing demand for fully qualified teachers.

Nonetheless, the 1998-99 production of approximately 22,000 degree graduates in special education teaching fields (approximately 9,600 at the bachelor's level, and 12,300 at the master's level) may seem more than an adequate supply to satisfy the demand for over 13,000 first-time entering SETs needed for the 199900 school year (see Table 3). However, of the
12,300 master's degree graduates in special 'education, our analyses of SASS data from 1999-00 suggests that a substantial majority (approximately 10,000 ) were already employed as teachers at the time of degree completion. Therefore, these already-employed graduates were not available to supply the demand in special education for entering first-time teachers. This left a net supply of about 12,000 unemployed graduates with teacher preparation majors in a field of special education to satisfy the total demand for 13,292 first-time entering SETs (see bottom row of Table 3).

It is clear that the recent production of degree graduates in special education (presumably with extensive teacher preparation) shown in Figure 2 was simply insufficient to yield the 13,292 entering first-time SETs hired in 199900 (as shown in Table 3). To satisfy the demand of first-time teachers in special education, individuals were hired who completed teacher preparation in general education, or who had only some or no preparation for teaching. 
TESE, Volume 30, No. 4

Fall 2007
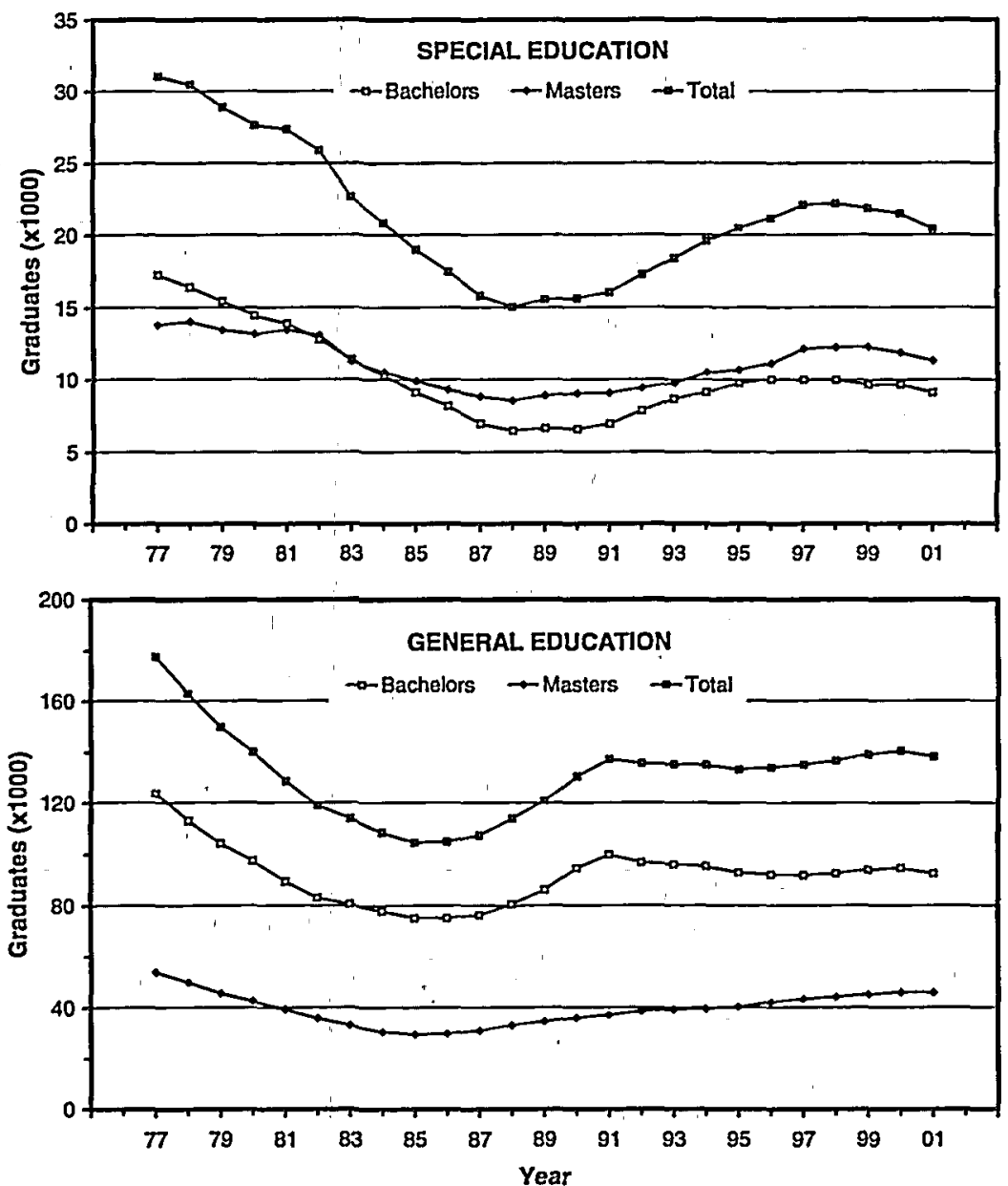

Figure 2. Number of Degree Graduates (Thousands) with Majors in Teacher Preparation Programs as a Function of Year and Degree Level. Data from the Integrated Postsecondary Education Data System (IPEDS) of the National Center for Educational Statistics, USDE

\section{Conclusion}

This study provides the first national information specifically on (a) the national supply of first-time SETs and GETs as a function of the amount of teacher preparation (i.e., extensive, some, or none), and (b) trends from $1987-88$ to $1999-00$ in the national supply of entering and continuing teachers. Since these results are based on large nationalprobability samples of public school teachers, they should not be interpreted as directly applicable to the state or local levels unless supported by other daca from the relevant level. For example, shortage of SETs might be greater in urban than suburban school districts - an important topic for further research. Given this caveat, the current findings support the following general conclusions about the national teaching force in public schools:

1. There was a slight increase in the percentage of continuing SETs during the 12-year period from 1987-88 through 1999-00. By comparison, there was a slight decrease in the percentage of continuing GETs. Thus, by 1999-00, the percentage of continuing teachers in both fields was virtually equal (slightly over $92 \%$ of total teachers in each field). In this important 
respect, equality was attainted in the yearto-year stability of the teaching forces in special and general education.

2. By the end of this 12-year period in 199900 , the percentage of first-time entering SETs (of total SETs) had increased to a level equivalent to that of entering GETs (i.e., $4.0 \%$ and $4.3 \%$, respectively). Similarly, the percentage of entering experienced SETs had declined to a level equivalent to that of entering GETs (i.e., $3.8 \%$ and $3.6 \%$, respectively). In these respects, both special and general education recruited in equivalent proportions from the two main sources, of entering teachers by 1999-00.

3. Among all entering teachers in 1999-00, the reserve pool (composed of reentering experienced teachers and delayed entrants with teacher preparation) was the predominant source of supply in both special and general education (i.e., about $63 \%$ in each field). Recent graduates who were firsttime prepared teachers were a distant second (about $25 \%$ in each field). In these and other respects, the sources of supply of entering teachers in special and general education were comparable.

4. Noteworthy differences between special and general education appeared in the supply of first-time teachers. Only $46.4 \%$ of all first-time SETs had completed extensive teacher prepararion with degree majors in their primary areas of teaching (i.e., special education), whereas the comparable figure for general education was $81.9 \%$. About $28 \%$ of first-time SETs with extensive preparation had degree backgrounds that prepared them for assignments in general education-a strong indication of the shortage in the supply of first-time teachers appropriately prepared to teach in special education.

5. In spite of the serious shortage of sufficient numbers of traditionally prepared teachers in special education, there has actually been a gradual decline in the annual numbers of such graduates since 199798. Thus, in spite of high demand, the supply of traditionally prepared teachers in special education is decreasing instead of increasing as needed. As of 1999-00, even SETs with only some preparation were not sufficient to meet the demand; however, teachers prepared for general education assignments were hired to fill almost 4,000 open positions in special education.

The national findings produced here demonstrate that special education competes on even terms with general education for the supply of teachers from multiple sources for entering and continuing teachers-excepr in one critical respect. That is, to fill open teaching positions, special education must resort to hiring a considerable proportion of first-time teachers who have completed preparation for general education positions. Nonetheless, policy makers have allowed the new supply of traditionally-prepared teachers in special education to decline in recent years. Instead, there is proliferation in the preparation of teachers in ARC programs for special education, a strategy that some assert will produce teachers with fewer qualifications and higher turnover than traditionally prepared teachers (Rosenberg \& Sindelar, 2001). While these misgivings may not apply to all ARC programs, Rosenberg and Sindelar recognize that much more needs to be known about the products of ARC programs before it is clear that this approach is effective in addressing the shortage of qualified and committed teachers in special education. Further, it is clear that if meaningful analyses of the quality and impact of ARC is to occur, it will be necessary to distinguish among the several variations of ARC.

Given that the reserve pool constitutes the predominant source of individuals entering the teaching force in public education, the size and character of this pool should be of tremendous interest to education policy makers, administrators, and researchers. Nonetheless, virtually nothing is known about the total reserve pool only about the subset of its members who have been recruited to enter teaching and who are thereby included in existing national and state data bases of employed teachers. The possibility of a shrinking reserve pool, a decline in the qualifications of, or a narrowing of the teaching fields represented, constitutes a serious threat to maintaining an adequate supply of entering teachers in the years ahead while the demand for teachers continues to grow as the school-age population expands. Thus, the extent and 
character of the total reserve pool of teachers should be a prime topic for intensive research.

In contrast with the position taken here that there is a serious shortage in the supply of entering teachers with extensive preparation for teaching in special education, others have advocated that the main problem lies in excessive turnover (i.e., inadequate retention) and not in a shortage of teacher supply (National Commission on Teaching and America's Future, 2003). While it is true that the demand for entering teachers could be reduced somewhat by improving the retention of employed SETs, this is nor likely to become a major factor in reducing the need for entering teachers. The turnover of SETs is not much different from that of GETs. The annual exit attrition percentage of SETs and GETs is very similar, and the number (not percentage) of SETs switching annually to general education is nearly offser by the number GETs switching to special education (Boe, Bobbitt, Cook, \& Barkanic, 1998). Furthermore, only $25 \%$ of beginning teachers (those in their first three years of teaching) who leave the profession report doing so for reasons that might be responsive to improved retention strategies (i.e., to find a different job or because of dissatisfaction with teaching). This means that $75 \%$ of teachers in their first three years leave for reasons (i.e., personal and family reasons, to return to school, and school staffing actions) that are likely to be impervious to improved retention strategies (Boe et al.).

Other evidence indicates that the attrition of beginning teachers is even less than that reported for other professions (Henke, Zahn, \& Carroll, 2001; Wayne, 2000). Therefore, the teacher shortage problem seems to be more one of inadequate supply of entering teachers instead of inadequate retention of employed teachers under current conditions prevailing in public schools. In any event, the problem of teacher retention in special education is equivalent to that in general education. If improvements in retention are to be won, it is likely to be across the profession. Of course, improvements in working conditions, compensation, and respect for teachers designed to improve retention will make the profession more attractive - improvements that are also likely to enhance the supply of teachers drawn from the reserve pool, as well as attract more college students to teaching as a career choice.

The data on SET supply and demand reported here pertain specifically to the annual quantity demand for entering teachers to fill open positions. In addition, there was an even larger quality demand to replace 49,000 less than fully-certified SETs practicing in 2001-02 (OSEP, 2004). The shortage of fully-certified SETs has been growing each year since 199394, as recorded in OSEP's Annual Reports to Congress and Boe and Cook (in press). When this demand is combined with the annual demand for entering teachers, there is an enormous unmet need for qualified SETs that is unlikely to be met in the near future regardless of modest increases in the production of new teachers and recruitment from the other available sources reported here. This should continue to engage the attention and efforts of policy makers who are responsible for providing an education for students with disabilities. Studies related to the numbers of teachers supplied by various sources (supplemented by other studies on teacher qualifications) can provide policy makers with information helpful to understanding the magnitude and complexities of the teacher shortage problem, thereby contributing to the design of more effective solutions.

\section{References}

Boe, E. E., Bobbitr, S. A., Cook, L. H., \& Barkanic, G. (1998). National Trends in Teacher Supply and Turnover for Special and General Education. (Data Analysis Rep. No. 1998-DAR1). Philadelphia: University of Pennsylvania, Graduate School of Education, Center for Research and Evaluation in Social Policy. (ERIC Document Reproduction Service No. Ed 426 549)

Boe, E. E., \& Cook, L. H. (in press). The chronic and increasing shorrage of fully-certified teachers in special and general education. Exceptional Children.

Boe, E. E., Cook, L. H., Kaufman, M. J., \& Danielson, L. (1996). Special and general education teachers in public schools: Sources of supply in national perspective. Teacher Education and Special Education, 19, 1-16.

Boe, E. E., Cook, L. H., Paulsen, C. A., Barkanic, G., \& Leow, C. S. (1999). Productivity of Teacher Preparation Programs: Surplus or Shortage in Quantity and Quality of Degree Graduates. (Data Analysis Rep. No. 1999-DAR2). Philadelphia: University of Pennsylva- 
nia, Graduate School of Education, Center for Research and Evaluation in Social Policy.

Brownell, M. T., Hirsch, E., \& Seo, S. (2004). Meeting the demand for highly qualified special education teachers during severe shortages: What should policymakers consider? Journal of Special Education, 38, 56-61.

Carison, E., Brauen, M., Klein, S., Schroll, K., \& Willig, W. (2002). Key Findings from the Study of Personnel Needs in Special Education. Washington, DC: Office of Special Education Programs, U.S. Department of Education.

Carriker, W., \& Weintraub, F. J. (1989). A Free Appropriate Education: But Who Will Provide It? A statement presented to the Senate Subcommittee on the Handicapped and the House Subcommittee on Select Education on behalf of the American Speech-LanguageHearing Association, Council of Administrators of Special Education, The Council for Exceptional Children, Council of Graduate Programs in Communication Sciences and Disorders, Higher Education Consortium for Special Education, National Association of State Directors of Special Education, and the Teacher Education Division of CEC.

Council for Exceptional Children. (2000). Bright futures for exceptional learners: Introduction-An action agenda to achieve quality conditions for teaching and learning. Reston, VA: Author.

Henke, R. R. Choy, S. P., Geis, S., \& Broughman, S. P. (1996). Schools and staffing in the United States: A statistical profile, 1993-94. Washington, DC: National Center for Education Statistics, U.S. Department of Education.

Henke, R. R., Zahn, L., \& Carroll, C. D. (2001). Attrition of New Teachers Among Recent College Graduates: Comparing Occupational Stability among 1992-93 Graduates Who Taught and Those Who Worked in Other Occupations. Washington, DC: 'National Center for Education Statistics, U.S. Department of Education.

Kozleski, E., Mainzer, R., \& Deshler, D. (2000). Bright Futures for Exceptional Learners: An Agerida to Achieve Quality Conditions for Teaching and Learning. Reston, VA: Council for Exceptional Learners.

McLeskey, J., Tyler, N. C., \& Flippen, S. S. (2004). The supply and demand for special education teachers: $A$ review of research regarding the chronic shortage of special education teachers. Journal of Special Education, 38, 5-21.

Miller, M. D., Brownell, M. T., \& Smith, S. W. (1999). Factors that predict teachers staying in, leaving, or transferring from the special education. Exceptional Children, 65, 201-218.

National Association of State Directors of Teacher Education \& Certification. (2003). The NASDTEC Manual on the Preparation and Certification of Educational Personnel 2003 ( $8^{\text {th }}$ ed.). Sacramento, CA: School Services of California, Inc.

National Clearinghouse on Professions in Special Education. (1992). Who will teach? Who will serve? A Report to the Field by"the Task Force on a National Personnel Agenda for Special Education and Related Services. Arlington, VA: National Association of State Directors of Special Education.

National Commission on Teaching and America's Future. (1996). What Matters Most: Teaching for America's Future. Washington, DC: The National Commission on Teaching \& America's Future.

National Commission on Teaching and America's Future. (2003). No dream denied: A Pledge to America's children. New York: The National Commission on Teaching \& America's Future.

Office of Special Education Programs. (1998). Twentieth Annual Report to Congress on the Implementation of the Individuals with Disabilities Education Act. Washington, DC: U.S. Department of Education.

Office of Special Education Programs. (2000). Twenty-second Annual Report to Congress on the Implementation of the Individuals with Disabilities Education Act. Washington, DC: U.S. Department of Education.

Office of Special Education Programs. (2002). Twenty-Fourth Annual Report to Congress on the Implementation of the Individuals with Disabilities Education Act. Washington, DC: U.S. Department of Education.

Office of Special Education Programs. (2004). Twenty-Sixth Annual Report to Congress on the Implementation of the Individuals with Disabilities Education Act. Washington, DC: U.S. Department of Education.

Office of Special Education Programs. (2005). Twenty-Seventh Annual Report to Congress on the Implementation of the Individuals with Disabilities Education Act. Washington, DC: U.S. Department of Education.

Rosenberg, M. S., \& Sindelar, P. T. (2001). The Proliferation of Alternative Routes to Certification in Special Education: A Critical Review of the Literature. Arlington, VA: The National Clearinghouse for Professions in Special Education, the Council for Exceptional Children. Available from the Web site: http://www.copsse.org/

Sindelar, P. T., Daunic, A., \& Rennells, M. S. (2004). Comparisons of traditionally and alternatively trained teachers. Exceptionality, 12(4), 209-223.

Snyder, T. D., \& Hoffman, C. M. (2003). Digest of education statistics: 2002. Washington DC: National Center for Education Statistics, U.S. Department of Education.

Tourkin, S. C., Pugh, K. W., Fondelier, S. E., Parmer, R. J., Cole, C., \& Jackson, B., et al. (2004). 1999-2000 Schools and Staffing Survey (SASS) Data File User's Manual (NCES 2004-303). Washington, DC: U.S. Department of Education.

U.S. Department of Education, Office of Special Education and Rehabilitative Services. (2002). A New Era: Revitalizing Special Education for Children and Their Families. Washington, DC,

Wayne, A. J. (2000). Teacher supply and demand: Surprises from primary research. Education Policy Analysis Archives, 8(47) 
Zabel, R. H., \& Zabel, M. K. (2001). Revisiting Burnout among Special Education Teachers Do Age, Experience, and Preparation Still Matter? Teacher Education and Special Education, 24, 128-39.

Lynne H. Cook, College of Education, California State University, Dominguez Hills; Erling E. Boe, Graduate School of Education, University of Pennsylvania.

\section{Appendix}

\section{Technical Supplement: Teacher Definitions, Sources of Teacher Supply, and Analysis Procedures}

\section{Teacbers Studied}

\section{Teacher Definition}

In keeping with the SASS definition, a teacher was any individual who reported being employed either full-time or part-time at a public school with a main assignment in any grade(s) $\mathrm{K}-12$, including itinerant teachers and long-term substitutes. Excluded from this definition of a teacher were individuals who identified their main assignment as pre-kindergarten teacher, short-term substitute, student teacher, teacher aide, or a non-teaching specialist of any kind.

\section{Definitions of Special and General Education Teachers}

The PSTQ asked teachers to designate one of 64 "main teaching assignment fields" as "the field in which you teach the most classes." We grouped these 64 fields into two main areas: special education and general education. Special education included 15 main teaching assignment fields such as deaf and hard-ofharing, developmentally delayed, and learning disabilities. All teachers who designated one of these 15 fields as their main teaching assignment were defined as SETs. Given that the PSTQ included a category for "other special education," all elementary and secondary teachers with a main assignment in any area of special education should have been able to identify themselves as such, regardless of the particular certification terminology used in their home state. GETs were then defined as all public school teachers (K-12) other than SETs.

\section{Teacher Sample}

The 1999-2000 PSTQ provides nationally representative estimates of the numbers of public school teachers of the various types analyzed in this research. Specifically, PSTQ data were obtained from a large national probability sample of public school teachers $(\mathrm{N}=53,105$, including public charter school teachers) with a weighted questionnaire response rate of $83 \%$. This yielded a sample of $44,896 \mathrm{~K}-12$ reachers who completed the PSTQ (4,919 SETs; 39,977 GETs). Teacher sample sizes for the 1997-98, 1990-91, and 1993-94 SASS administrations are reported in Table 1 . There are no missing data for completed PSTQs because NCES impured values for item nonresponse. Detailed information about the 1999-2000 SASS is provided by Tourkin et al., 2004.

\section{Sources of Teacher Supply}

The specific sources of teacher supply depicted in Figure 1 are defined below:

1. Entering teachers. Entering teachers were defined as individuals who where not teaching in public schools during one school year, and who commenced teaching in a public school during the subsequent school year. Entering teachers were first subdivided into those who were first-time teachers and those who had prior teaching experience.

a. Entering teacher supply: First-time teachers. Entering first-time teachers were those who had no prior teaching experience in either public or private schools, other than possibly as teacher aides, student teachers, or shortterm substiture teachers. First-time teachers were subdivided into those who completed different amounts of teacher preparation prior to entering teaching.

(1) Amount of Teacher Preparation. Teachers differ widely in the amount of preparation in pedagogy and supervised teaching they complete. PSTQ provides information for each first-time teacher that can be used to define three ordered categories of the amount of teacher preparation completed (extensive, some, or none). One item of information available is the length of the practice teaching experience: 10 weeks or more, 5 to 9 weeks, 1 to 4 weeks, or no practice teaching. Other items of information available are completion of each of four common components of teacher preparation: (a) coursework in selecting and adapting instructional materials, (b) coursework in educational psychology, (c) observation of other classroom teaching, and (d) received feedback on their teaching. Completion of extensive practice teaching and these common com- 
ponents are ordinarily required by states for teachers to become certified. According to data from 50 states and the D.C. produced by NASDTEC, 8 weeks of practice teaching is the minimum number required for an initial teaching certificate (NASDTEC, 2003, Table B8). In addition, almost all states require coursework in the psychological foundations of teaching, teaching methods, and field experience prior to student teaching (NASDTEC, 2003, Tables B-5, B-6, and $B-7)$. Given this background and using parcicular combinations of (a) length of the practice teaching experience available from PSTQ and (b) number of four common components of teacher preparation completed, it was possible to define operationally two levels of teacher preparation in pedagogy and supervised teaching, as follows:

(a) Extensive teacher preparation: Extensive teacher preparation was defined as completing either (a) 10 or more weeks of practice teaching along with all four of the common components of traditional teacher preparation listed above, or (b) 10 or more weeks of practice teaching and three of the four common components of traditional teacher preparation, or (c) 10 or more weeks of practice teaching and less than three of the four common components of traditional teacher preparation, or (d) 5-9 weeks of practice teaching along with all four common components of teacher preparation. The percentages of the sample of first-timie teachers so classified are $79 \%, 9 \%, 2 \%$, and $10 \%$, respectively.

(b) Some teacher preparation: Some teacher preparation was defined as completing either (a) 5-9 weeks of pracrice teaching and some of the four common components of traditional teacher preparation listed above, or (b) $1-4$ weeks of practice teaching and all or some of the four common components of teacher preparation, or (c) no practice teaching but all four common components of teacher preparation. The percentages of the sample of first-time teachers so classified are
$23 \%, 36 \%$, and $41 \%$, respectively. Only $14 \%$ of teachers classified here completed less than three of the four common components of teacher preparation.

(2) Little or no teacher preparation: All other teachers 'without practice teaching were defined as having little or no teacher preparation. Of the sample of such firsttime teachers, $32 \%$ did nor complete any of the four common components of teacher preparation listed above, while $68 \%$ completed from one to three of these four components.

b. Entering teacher supply: Experienced teachers. Entering experienced teachers were not employed as teachers in public schools during the prior year. Entering experienced teachers were of two subtypes, as follows:

(1) Reentering experienced teachers. Reentering experienced teachers were former teachers who had left teaching employment in either public or private schools. Such former teachers represent one component of the "Reserve Pool," a major source of supply of entering teachers. (The other component of the reserve pool is "delayed entrants," i.e., college graduates who have completed a significant amount of teacher preparation, but who have delayed entering teaching employment by more than one year following their graduation.)

(2) Private school migrant teachers. Private school migrant teachers are teachers who transferred teaching employment from private to public schools.

2. Continuing teachers. Continuing teachers were defined as teachers who were teaching in a public school during one school year, and who continued teaching in a public school during the next school year. A continuing teacher may have continued in the same school and teaching assignment, or may have changed school and/or teaching assignment from one school year to the next school year.

\section{Additional Teacher Supply Variables}

\section{Time of entry}

First-time teachers with teacher preparation were classified according to the number of years between 
college graduation and entry into the ranks of employed teachers, as follows:

1. Recent graduates. Recent graduates were entering first-time teachers with teacher preparation who had earned a college or university degree at the bachelor's or graduate levels during the year prior to entry to teaching (i.e., calendar year 1999).

2. Delayed entrants. Delayed entrants were entering first-time teachers with teacher preparation who had not earned a college or university degree at the bachelor's or graduate levels during caléndar year 1999, but who had earned a degree during some prior year. As stated above, delayed entrants represent one component of the "Reserve Pool," a major source of supply of entering teachers. (The other component of the reserve pool is experienced teachers who might elect to reenter teaching.)

\section{Field of degree major}

Teachers were also classified according to the academic or professional field(s) in which they had majored, as follows.

1. Degree majors in a field of teacher preparation. Teachers who had completed at least one major in a field of teacher preparation at either the bachelor or master's degree levels were classified as having a major in teacher preparation. Such teachers were further subdivided in those whose teacher preparation major was in special education vs. those whose teacher preparation major was in general education.

2. Other degree majors. All teachers who were not classified as having majored in a field of teacher preparation were classified as having other degree majors.

\section{Analysis Procedures}

Based on the sample of teachers completing the PSTQ, national estimates of the numbers of teachers of each type included in the design (along with associated percentages and standard errors) were computed by special procedures developed by NCES for complex sample survey data (Tourkin er al., 2004). The national estimates of teachers, and the sample sizes on which these estimates were based, are shown in the tables of this report.

Because SASS data are subject to design effects due to stratification and clustering of the sample, standard errors for the national estimates and tests of statistical significance were computed by the method of balanced repeated replications with software entitled WesVar Complex Sample Software 3.0. Chi-square tests of the statistical significance of differences among teacher supply variables as a function of teaching field (special vs. general education) were performed on the nationally estimated numbers of teachers. 